\title{
The Politics and Economics of Offshore Outsourcing
}

\section{Citation}

Mankiw, N. Gregory and Phillip Swagel. 2006. The politics and economics of dffshore outsourcing. AEI Working Paper Series.

\section{Published Version}

http://dx.doi.org/10.3386/w12398

\section{Permanent link}

http://nrs.harvard.edu/urn-3:HUL.InstRepos:2770517

\section{Terms of Use}

This article was downloaded from Harvard University's DASH repository, and is made available under the terms and conditions applicable to Other Posted Material, as set forth at http:// nrs.harvard.edu/urn-3:HUL.InstRepos:dash.current.terms-of-use\#LAA

\section{Share Your Story}

The Harvard community has made this article openly available.

Please share how this access benefits you. Submit a story.

Accessibility 
NBER WORKING PAPER SERIES

THE POLITICS AND ECONOMICS OF OFFSHORE OUTSOURCING

N. Gregory Mankiw

Phillip Swagel

Working Paper 12398

http://www.nber.org/papers/w12398

NATIONAL BUREAU OF ECONOMIC RESEARCH

1050 Massachusetts Avenue

Cambridge, MA 02138

July 2006

We are grateful to Alan Deardorff, Jason Furman, John Maggs, Sergio Rebelo, Alan Viard, Warren Vieth, and participants at the November 2005 Carnegie-Rochester conference for helpful comments. The views expressed herein are those of the author(s) and do not necessarily reflect the views of the National Bureau of Economic Research.

(C)2006 by N. Gregory Mankiw and Phillip Swagel. All rights reserved. Short sections of text, not to exceed two paragraphs, may be quoted without explicit permission provided that full credit, including (C notice, is given to the source. 
The Politics and Economics of Offshore Outsourcing

N. Gregory Mankiw and Phillip Swagel

NBER Working Paper No. 12398

July 2006

JEL No.

\begin{abstract}
This paper reviews the political uproar over offshore outsourcing connected with the release of the Economic Report of the President (ERP) in February 2004, examines the differing ways in which economists and non-economists talk about offshore outsourcing, and assesses the empirical evidence on the importance of offshore outsourcing in accounting for the weak labor market from 2001 to 2004. Even with important gaps in the data, the empirical literature is able to conclude that offshore outsourcing is unlikely to have accounted for a meaningful part of the job losses in the recent downturn or contributed much to the slow labor market rebound. The empirical evidence to date, while still tentative, actually suggests that increased employment in the overseas affiliates of U.S. multinationals is associated with more employment in the U.S. parent rather than less.
\end{abstract}

\author{
N. Gregory Mankiw \\ Department of Economics \\ Harvard University \\ Cambridge, MA 02138 \\ and NBER \\ ngmankiw@harvard.edu \\ Phillip Swagel \\ American Enterprise Institute \\ 1150 Seventeenth Street NW \\ Washington, DC 20036 \\ pswagel@aei.org
}




\title{
The Politics and Economics of Offshore Outsourcing ${ }^{1}$
}

\author{
N. Gregory Mankiw \\ Harvard University \\ Phillip Swagel \\ American Enterprise Institute
}

\section{Introduction}

During the presidential campaign of 2004, no economic issue generated more heat or shed less light than the debate over offshore outsourcing. This fact was probably apparent at the time to any economist who followed politics, but it was felt especially acutely by the authors of this paper. We were then working at the Council of Economic Advisers as, respectively, chairman and chief of staff. While the job of the CEA is to focus on the economics of current policy debates, the environment in which that job is performed is highly political, especially in an election year. To some extent, therefore, this paper is a report from inside the eye of a storm.

Our goal is both to describe the heat and then to shed some light. The first part of the paper focuses on the politics, describing the outsourcing debate of 2004. We document how popular concern about outsourcing increased during 2003 and accelerated as the presidential election of 2004 approached. A focal point of the politics was the release of the Economic Report of the President (ERP) in February 2004. The Presidential campaign of Senator John Kerry seized on the issue of outsourcing, lambasting President Bush and his advisers for supposedly favoring it, and put forward a corporate tax proposal allegedly aimed at removing tax incentives for U.S. firms to move jobs overseas. At about the same time, economist Paul Samuelson made headlines with an article that was widely and wrongly interpreted (including apparently by Samuelson himself) as suggesting a retreat from economists' historical consensus in support of free

\footnotetext{
${ }^{1}$ We are grateful to Alan Deardorff, Jason Furman, John Maggs, Sergio Rebelo, Alan Viard, Warren Vieth, and participants at the November 2005 Carnegie-Rochester conference for helpful comments.
} 
trade. After the November election, media interest in outsourcing as a topic subsided, although it remained higher than two years earlier.

The second part of this paper surveys the empirical literature on offshore outsourcing, with an emphasis on outsourcing of business services. Work to quantify the impact of increased trade in services on domestic labor markets has lagged behind popular interest, in no small part because existing data sources make it difficult to identify job changes related to trade in business services. Indeed, gaps in the available data make it difficult to say how many jobs are being outsourced and why. The empirical literature is able, however, to conclude that offshore outsourcing is unlikely to have accounted for a meaningful part of the job losses in the recent downturn or contributed much to the slow labor market rebound.

To a large extent, the issue of offshore outsourcing involves the same fundamental questions addressed by economists for more than two centuries concerning the impact of international influences on the domestic economy. To be sure, the world is different, as advances in technology have made it possible to trade a wider range of services. Services offshoring, however, fits comfortably within the intellectual framework of comparative advantage built on the insights of Adam Smith and David Ricardo. This is contrary to the assertions of some non-economists, who see a new paradigm created by improved technology and communications that somehow undermines the case for free trade.

The theoretical literature on offshoring has been mainly positive, focusing on the factors influencing firms' choice of organizational structure and location of production. There has been little normative analysis on the welfare impact of offshoring. This is perhaps because economists see outsourcing as simply a new form of international trade, which as usual creates winners and losers but involves gains to overall productivity and incomes. 
Moreover, the empirical evidence, while still tentative, suggests that increased employment in the overseas affiliates of U.S. multinationals is associated with more employment in the U.S. parent rather than less. These econometric results are buttressed by similar findings in the business literature, where researchers from McKinsey Consulting calculate that overall net U.S. income rises by about 12-14 cents for every dollar of outsourcing (that is, gross income rises by $\$ 1.12-1.14$ ).

There are costs to services outsourcing, and these costs are familiar from the literature on how trade in goods affects labor markets. While trade provides benefits for the nation as a whole, some people face dislocation. For example, workers with low skills within certain occupations such as data entry and low-end computer programming appear to have been affected by increased trade in services. The appropriate policy response is to help affected workers adjust to change rather than give up the gains from trade in the first place. Policies aimed at preventing trade, including outsourcing, would mean lower standards of living for both Americans and the citizens of developing countries.

The message from economists that international trade in services is nothing new and likely to be beneficial is enormously frustrating to non-economists, especially politicians. To help bridge this communications gap, we examine the differing ways in which economists and non-economists talk about offshoring, focusing on ways in which economists can communicate more effectively to policymakers and the broader public. These lessons have been learned from experience.

\section{The Politics of Outsourcing}

The topic of offshore outsourcing is as much a political topic as an economic one, and perhaps even more so. We therefore begin by discussing the politics, as seen through the eyes of economists working at the White House during an election year. 


\section{Rising Attention to Outsourcing}

Interest in outsourcing exploded in 2004, with over 1,000 references to the subject in four major newspapers ${ }^{2}$ that year, compared to fewer than 300 references in each of the previous two years (Figure 1). Discussions of outsourcing figured prominently in the popular culture, including jokes by late night television talk show hosts, scores of editorial cartoons, and ongoing attention on television programs such as the Lou Dobbs Tonight show on CNN (on which the first author appeared as a guest). In the electoral battleground state of Ohio, outsourcing was the focus of numerous political television and radio commercials by the Kerry campaign and like-minded groups such as MoveOn.org. In Washington, DC, and elsewhere, outsourcing was the subject of countless press conferences and panel discussions. One such event was a January 7, 2004 event at the Brookings Institution in which Senator Charles Schumer (D-NY) and Reagan-administration Treasury official Paul Craig Roberts discussed their idea that changes in the modern global economy had undermined the centuries-old case for free trade, as they put it in an op-ed in the New York Times the previous day. Schumer and Roberts pointed to outsourcing of software engineers and radiologists as exemplifying the concerns arising from free trade. Their thesis that increased capital mobility means that comparative advantage and the resulting gains from trade no longer apply to the modern economy is a fallacy. Indeed, having this event at Brookings was akin to the Mayo Clinic hosting a discussion on the benefits of laetrile. And yet, it highlights the partisan attention given to outsourcing even before the ERP release.

\footnotetext{
${ }^{2}$ The New York Times, Washington Post, Los Angeles Times, and USA Today.
} 
Figure 1: Media References to "Outsourcing"

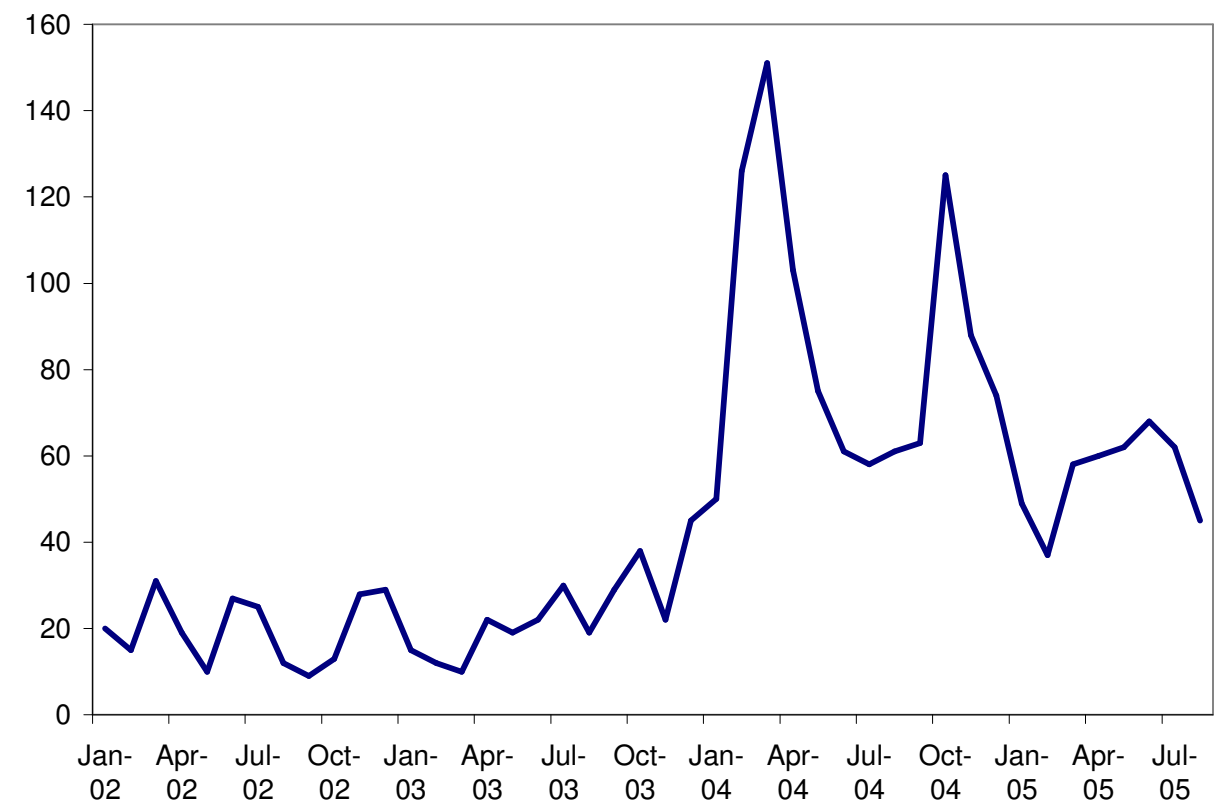

The timing of attention to outsourcing in 2004 indicates as well the close connection to the electoral cycle. Mentions of the word "outsourcing" in the four major newspapers in Figure 1 spiked after the release of the ERP in February 2004 and then soared again just before the Presidential election in November. Even so, interest in outsourcing had been rising before February 2004, with mentions in the four newspapers increasing from an average of about 20 per month in 2002 and the first half of 2003 to about 50 per month at the end of 2003 and in January 2004. Given this, it seems likely that outsourcing would have arisen as a major campaign issue at some point. The events surrounding the release of the ERP served as a catalyst to hasten that date.

Underlying the rising concern over the impact of outsourcing on U.S. labor markets was what many observers saw as a tepid labor market recovery following the economic slowdown of 2000 and 2001. Output in the U.S. manufacturing sector experienced a pronounced slowdown starting in July 2000, while broader measures of activity on which recession dating is focused such as real personal incomes minus transfers and the volume of manufacturing and wholesale-retail sales reached a plateau by late 2000. The labor market, as usual a lagging indicator, peaked in February 2001, 
several months after activity judged by the other measures had begun to decline. Nearly 750,000 jobs were lost in the first 6 months of the labor market slowdown, and then another 1.3 million jobs were lost in the 6 months after the 9/11 terrorist attacks (over 900,000 in the first 3 months). The labor market lagged even after steady GDP growth resumed in late 2001, possibly because growth remained too modest to take up the resources freed up by the downturn. A modest uptick in job growth began in September 2003, but a solid labor market recovery came only around March 2004 (meaning it was evident in official statistics in April and later). Wages likewise stagnated despite strong productivity growth, with real hourly earnings growing less than 1 percent per year from 1999 to 2003 (though overall compensation grew more robustly with a surge in non-wage compensation such as employer-provided healthcare).

Against the backdrop of a faltering labor market, outsourcing became synonymous in the public debate with job loss, and the transfer of jobs overseas came to be seen by non-economists as a major factor in accounting for the weak job market of 2002 and 2003. The release of the Economic Report of the President in early 2004 thus came at a time when the recovery was still not viewed as robust. ${ }^{3}$ Moreover, the Presidential campaign was in full gear, with Senator Kerry on the verge of knocking his primary opponents out of the race. Looking ahead to the general election, the Kerry campaign was naturally seeking to seize upon any issue to highlight economic problems.

\section{The Economic Report of the President and the Political Hysteria of 2004}

The 2004 Economic Report of the President was released in the morning on Monday, February 9. The CEA chairman (the first author of this paper) held a press conference that day, and then participated in an online question-and-answer session on the "Ask the White House" feature of the White House website. The chairman and

\footnotetext{
${ }^{3}$ Many White House staffers likewise did not see the economy as growing strongly; it is fair to say that foreign policy was seen as the strength of the Administration at that point, despite indicators such as the 8.2 percent annual GDP growth in the third quarter of 2003 (which was "only" 7.2 percent in the initial release).
} 
members of the Council participated in a Congressional hearing on the Report on Tuesday, February 10 before the Joint Economic Committee, and the chairman gave a long-planned speech to the National Economists Club on the major themes of the Report on February 17.

As usual, the 2004 Report included a chapter on international trade. This chapter included a section on trade in services with the following paragraph on outsourcing (on page 229):

One facet of increased services trade is the increased use of offshore outsourcing in which a company relocates labor-intensive service industry functions to another country. For example, a U.S. firm might use a call center in India to handle customer servicerelated questions. The principal novelty of outsourcing services is the means by which foreign purchases are delivered. Whereas imported goods might arrive by ship, outsourced services are often delivered using telephone lines or the Internet. The basic economic forces behind the transactions are the same, however. When a good or service is produced more cheaply abroad, it makes more sense to import it than to make or provide it domestically.

This last sentence, though a plain statement of the reason why trade arises, was later to be seen in the press and on Capital Hill as an affront to American workers. ${ }^{4}$

Outsourcing was the topic of two questions at the press conference. It is useful to reproduce the complete answers to these questions to illustrate just how far out of context the subsequent public discussion was to take the comments made at the press conference. The response to the first question on outsourcing was:

I think outsourcing is a growing phenomenon, but it's something that we should realize is probably a plus for the economy in the long run. Economists have talked for years about trade, free international trade, being a positive for economies around the world, both at

\footnotetext{
${ }^{4}$ A variant of the sentence was included in the Overview at the front of the Report: "When a good or service is produced at lower cost in another country, it makes sense to import it rather than to produce it domestically. This allows the United States to devote its resources to more productive purposes." (page 25)
} 
home and abroad. This is something that is universally believed by economists. The President believes this. He talks about opening up markets abroad for American products being one of his most important economic priorities. And we saw discussions this weekend of the Australia agreement. So it's a very important priority.

When we talk about outsourcing, outsourcing is just a new way of doing international trade. We're very used to goods being produced abroad and being shipped here on ships or planes. What we're not used to is services being produced abroad and being sent here over the Internet or telephone wires.

But does it matter from an economic standpoint whether values of items produced abroad come on planes and ships or over fiber optic cables? Well, no, the economics is basically the same. More things are tradable than were tradable in the past, and that's a good thing.

That doesn't mean there's not dislocations; trade always means there's dislocations. And we need to help workers find jobs and make sure to create jobs here. But we shouldn't retreat from the basic principles of free trade. Outsourcing is the latest manifestation of the gains from trade that economists have talked about at least since Adam Smith.

Notice that the order of response was to first note the gains from trade, and only second to refer to the dislocation to affected workers; later we will discuss how, from a communications standpoint, this was a tactical error. The following elaboration was given in response to a question near the end of the press conference asking for more clarification on outsourcing:

Well, I think there's a tendency among some people to believe that outsourcing is a different phenomenon than trade. And from an economic standpoint, it really isn't. Whether things of value, whether imports from abroad, come over the Internet or come on ships, the basic economic forces are the same.

There is a fundamental misunderstanding about trade in general. For years, there's been a temptation to somehow think that trade is zero sum, that when some country benefits from trade, we must be losing from trade. 
One of the things we teach in basic economics courses, and the economics profession is as unanimous on as they are on anything, is that trade is win/win, that both trading partners can benefit from a free and open trading system. And that's why the President has told [then-U.S. trade representative] Bob Zoellick to go out there and negotiate free trade agreements and why opening up markets abroad is so important and reducing trade barriers and not retreating from free trade is this administration's policy.

It was not at all clear following the press conference that a political firestorm was in the making. Indeed, reporters from the Financial Times, USA Today, and the Wall Street Journal complained at the end of the press conference that there had not been any news. A reporter from the Washington Post suggested after the event that the answer on outsourcing might be controversial, but more because of the inherently contentious nature of the topic than the precise words. A staffer from the White House press office who had attended the event likewise saw the responses to the outsourcing questions as potentially problematic. An interesting distinction is that the reporters who missed the story at first were among the best in the Washington press corps in terms of their economic knowledge. The FT and Wall Street Journal reporters had the backgrounds one would expect of economics writers for those publications, while the reporter for USA Today was a 1995 graduate of Harvard who had majored in economics and written on the subject for the FT before moving to the mass-circulation USA Today. For these reporters (as for ourselves), a focus on the economic substance meant overlooking the newsworthy point that a White House adviser was talking straightforwardly about the subject of outsourcing in the first place during an election year.

With the concerns of the press office staffer in mind, a question on outsourcing was intentionally addressed in the online chat session that followed the press conference. In response to the query of "How does outsourcing affect the US economy?" posed by Michelle from San Diego, an answer was given that discussed both the gains and dislocations from trade, noting that the proper policy response was to ease the transition 
of workers. This answer was similar to the text from the Report itself and to what had been said in the press conference. ${ }^{5}$

An article about the ERP and the press conference in the Washington Post on Tuesday, February 10 noted the outsourcing comments but added that this was a mainstream idea "seconded by economists and business leaders." The focus instead, as with the news wire stories, was on the seemingly optimistic forecast for 3 percent job growth (which, indeed, turned out to be overly optimistic). The article ran in the Post's lightly read Business section, suggesting as well that the editors of the Post did not view this as a major story, even with the article's suggestion that the CEA conclusions on outsourcing "may prove discordant during an election year."

The controversy arose instead from coverage of the press conference in the Los Angeles Times. Above a nuanced discussion of the costs and benefits of outsourcing, the LA Times ran the incendiary (and inaccurate) headline "Bush Supports Shift of Jobs Overseas." In contrast, the Post headline above a similar story was "Bush Report Offers Positive Outlook on Jobs."

It took less than a day for the words "Bush Supports Shift of Jobs Overseas" to be picked up by opponents of the President. However, it took more than half a day for this to happen, so that the issue of outsourcing figured little at the Congressional hearing on the ERP on February 10 - the day of the inflammatory LA Times headline. The major

\footnotetext{
${ }^{5}$ The complete answer to the question was:
}

Outsourcing is the latest manifestation of the forces of free trade and increasing international specialization in production. We are all used to goods being produced abroad and transported here on ships or planes. We are less used to services being produced abroad and being transported here over telephone lines or the Internet. But the basic economic forces are the same.

An open world trading system is generally a positive contribution to economic prosperity. It increases living standards both at home and abroad. That is the reason the President has actively pursued trade agreements to open up markets abroad.

At the same time that we pursue a more open trading system around the world, we have to acknowledge that any economic change, including those that come from trade, can cause painful dislocations for some workers and their families. The goal of policy should be not to stop change but to ease the transition of workers into new, growing industries. The President's initiative to support education at community colleges is one example. 
political line of attack for Democratic members of the committee was instead to highlight weak job growth and question the administration economic forecast.

This changed within the same day's news cycle as politicians became aware of the headline in the LA Times and then opened the Report and found the sentence about cheap imports making sense. The next day, February 11, a story on the ERP in the Washington Post was headlined "Bush, Adviser Assailed for Stance on 'Offshoring' Jobs." This story was not relegated to the business section, but instead ran on page 6 of the front section, and quoted Senator Kerry decrying the White House desire to "export more of our jobs overseas," as well as Republican Congressman Donald Manzullo from Illinois calling for the resignation of the CEA chairman. White House aides responsible for Congressional liaison warned of fury on the part of Republican members of Congress from Pennsylvania, Ohio, Michigan, and other industrial states.

This Congressional anger broached the surface on Wednesday, February 11, when Speaker of the House Dennis Hastert released a statement blasting the discussion of outsourcing, and saying that CEA Chairman Mankiw's ideas had "failed a basic test of real economics." An effort among staffers for Republican Senators to have a similar statement from the other side of the Hill was squelched by a key staffer in Senator Frist's office. Even so, the story of the Republican Congressional leader attacking the White House was big news and ensured that outsourcing was to remain in the news for days to come.

An interesting note is that after the first day's stories on the ERP and the press conference, subsequent press coverage focused largely on the political response rather than the substance of what was actually written and said. Indeed, reporters writing the stories universally acknowledged in private that the CEA Report was both correct and unremarkable on the substance. What was remarkable was the reaction, and as journalists they were obligated to cover the political reaction and fallout. The coverage reflected the unfortunate reality of the modern craft of journalism. In general, the coverage did not 
seem to us to reflect malice, bias, or sloppiness on the part of the journalists involved. ${ }^{6}$ Matters of substance were left to editorial writers. The February 13, 2004 Washington

Post included an editorial (that is, from the newspaper itself, not from an outside contributor) titled "Mr. Mankiw is Right." Similar editorials appeared in the San Jose Mercury News, the Atlanta Journal-Constitution, Business Week, and a host of other magazines and newspapers. Even the New York Times editorial page, reflexively hostile to the Administration, was broadly supportive.

Backing came as well from economists across the political spectrum, with statements of support from Clinton Administration CEA chairs Laura Tyson, Janet Yellen, and Martin Baily, as well as from Clinton Labor Secretary Robert Reich. Fed Chairman Alan Greenspan was broadly supportive in Congressional appearances when asked about outsourcing. Notable in his initial silence was Paul Krugman, whose first writing on the ERP in his New York Times column was a (misleading) February 17, 2004 attack on the ERP's healthcare chapter. Only in late February did Krugman's column turn to his academic specialty of international trade. Krugman's February 27 column chided Senator Schumer for his association with the comeback of "old fallacies," but then went

\footnotetext{
${ }^{6}$ An exception in our eyes was a February 20, 2004 story in the New York Times by David Cay Johnson that asserted that the Economic Report "questions whether fast-food restaurants should continue to be counted as part of the service sector or should be reclassified as manufacturers. No answers were offered." Although the story in the Times fell short of saying that the Report urged reclassification, it intimated that the Report raised the question of whether some activities should be reclassified. This was an invention by the Times - the question of reclassifying any activities was never raised. The story was based on a box in the Report that discussed how the definition of manufacturing is not straightforward and therefore "Whenever possible, policy making should not be based upon this type of arbitrary statistical delineation." The box contained the sentence: "When a fast-food restaurant sells a hamburger, for example, is it providing a 'service' or is it combining inputs to 'manufacture' a product?" Somehow the Times decided that this and the rest of the box represented raising the question of whether to reclassify some activities, even though the word "reclassify" is not used. Moreover, the context of the box makes it clear that the ERP urges that classifications should not be used for policy decisions in the first place rather than that anything should be changed or even that any changes should be contemplated. The New York Times refused to correct the story, much to the ridicule of Washington-based journalists, who well understood that this was an error of fact. This article, however, resulted in further "controversy," with Democratic members of Congress urging the President to renounce the supposed desire by his staff to cover up declining employment in manufacturing through changes in measurement. The New York Times printed an article by a different writer a few days later, on February 26, noting that the uproar had missed the point in the ERP, without mentioning that the episode had been started by a misleading article in the Times itself. (The real intent of the box was to impede the movement in Congress to give lower corporate tax rates to manufacturing than non-manufacturing firms. Despite the fact that the distinction is inherently fuzzy and that the Administration opposed the legislation, it passed Congress attached to a bill that would eliminate the FSC/ETI export subsidy. Because the President wanted the export subsidy removed to become consistent with WTO rulings, he signed the bill.)
} 
on to lambaste President Bush and sprinkle kind words on Senator Kerry regarding trade - the same Senator Kerry who was running away from his record of support for free trade. Notable as well for his silence was then-Harvard President Larry Summers, who as Treasury Secretary had fought successfully against trade restrictions in steel until the last days of the Clinton Administration. (Summers declined when journalists asked him for an on-the-record comment on the outsourcing controversy, even though as Harvard President he had shown considerably less reluctance to engage in the public debate on other issues.) Within CEA, the feeling at times was that on the issue of outsourcing, it was the members of the American Economics Association (or at least all but a handful) and newspaper editorial boards against the rest of the U.S. population.

Until Speaker Hastert's statement, the belief within the White House was that having the CEA chair write an op-ed in a major newspaper such as the Washington Post to provide the full context of his remarks on outsourcing would be an appropriate and adequate response to the public debate - not a solution, since there was no way to put back this genie, but a response. Such an op-ed would have involved putting the full comments from the press conference into print. After all, in the full context, there is little remarkable about the substance of what was written in the Report or spoken at the press conference. Speaker Hastert's action changed this, as his anger required a direct response to him rather than an indirect one through a newspaper. The op-ed was converted into a letter from Mankiw to Mr. Hastert, which the White House press office then provided to reporters (who were in any case the main audience).

The letter told the Speaker that "Some of my recent comments on outsourcing have been misinterpreted"-an understatement if ever there was one - and went on that "My lack of clarity left the wrong impression that I praised the loss of U.S. jobs." Instead, the Speaker was told that any job loss was "regrettable"-an awful experience for a worker and their family. All true, but this had little relation to outsourcing, since there was no evidence that outsourcing had contributed meaningfully to U.S. job losses. The rest of the letter essentially restated what was said at the press conference, including that the right response to changing technology and increased global integration was a 
commitment to free markets. By contrast, "a retreat into economic isolationism" was deemed "a recipe for economic decline." This phrase-economic isolationism-was to figure broadly in the campaign to come and is discussed further below. Reporters took the letter as an apology and retraction, though the precise words of the letter were more a restatement than either of those.

The following Tuesday, on February 17, the Chairman gave a long-scheduled talk to the National Economic Club in Washington on the ERP. This address, unfortunately scheduled in a Chinese restaurant (though at least not an Indian one, given the connection of India to services outsourcing), was widely covered but produced little news. The talk itself connected concerns over international trade to the weak labor market, but noted that declining investment and exports, not import competition, were the main factors behind the weak labor market. Several questions on outsourcing received replies with more of the same. This created no further news. This was the case as well for myriad television, radio, and print interviews done by the CEA chair, most of which invariably touched on outsourcing.

With Senator Kerry attacking on trade, the counter adopted in the White House and by the President's reelection campaign was to connect Senator Kerry with "economic isolationism" and "economic pessimism"- to suggest that his view was of an America that could not compete. These themes were included in a March 10 speech by President Bush to the Women's Entrepreneurship Forum in Cleveland. After acknowledging concerns about jobs moving overseas, the President attacked "politicians in Washington" whose response was to "build a wall around this country and to isolate America from the rest of the world." Decrying the "defeatist" mindset of economic isolationism turned out to be a political winner. Spirits visibly lifted in the White House, and the Kerry campaign was momentarily forced to respond instead of attack. Economists in the Administration took heart at least that campaign strategists saw a positive value in declaring support for free trade even in a state that had hemorrhaged manufacturing jobs over the past four years. 
Within the White House, the issue of outsourcing was seen as moving off the front burner. To illustrate the value of the global economy, administration staffers compiled data on jobs created by "insourcing," meaning foreign firms operating in the United States. The President gave further speeches on the benefits of open markets, though typically this meant opening foreign markets to U.S. exports, and Senator Kerry retreated somewhat from his most brazen language concerning international trade. Nonetheless, everyone in the administration realized that outsourcing —or "ouchsourcing," as it was known by White House staffers involved with communications efforts-would remain an issue through the November election.

The CEA went back to its usual role in providing economic analysis, with the Chair and Members participating in their usual number of public events and media appearances. Oddly, a myth developed in the media that White House operatives had sought to restrict CEA public appearances. New York Times columnist Thomas Friedman, for example, stated as recently as May of 2005 that "Republicans put duct tape over the mouth of chief White House economist Greg Mankiw when he said outsourcing makes sense, and stashed him in Dick Cheney's basement—never to be heard from again." Friedman's best selling book, The World is Flat, repeats the claim. This is simply false. Indeed, the CEA chair took over the very public role of providing the Administration's televised response to the monthly jobs numbers, which through the campaign was a main focus of attention (along with outsourcing) in terms of the economic agenda. The chair appeared as well on the Lou Dobbs television show, though on a night when Mr. Dobbs' absence left his CNN colleague John King to make a halfhearted attempt at decrying outsourcing, with body language and off-camera discussion that made it clear that he knew better.

Outsourcing remained an issue throughout the election year of 2004. Indeed, staffers in the Bush-Cheney reelection campaign said that it was a constant issue in Ohio, a battleground state. Against this backdrop of continuous interest (as shown in Figure 1), outsourcing bubbled to the top of the public debate two additional times: when Senator Kerry put forward a policy proposal tied to outsourcing, and in September 2004, when 
eminent economist Paul Samuelson released a draft paper that he claimed touched on the subject.

\section{The Kerry Outsourcing Proposal}

After decrying outsourcing, Senator Kerry's campaign put forward a policy proposal aimed at it in March 2004. According to Senator Kerry, "if a company is torn between creating jobs in Michigan or Malaysia, we now have a tax code that encourages you to go overseas." He pledged to "repeal every tax break and loophole that rewards any Benedict Arnold CEO or corporation for shipping American jobs overseas." Oddly, at the time that Senator Kerry first started talking about tax incentives for outsourcing, the section on outsourcing on his campaign website had material relating to corporate inversions, the practice by which U.S. firms reorganize their corporate structure to move their headquarters to a low-tax jurisdiction such as Bermuda in order to avoid U.S. taxes on their overseas income. Unlike outsourcing, however, inversion involves no job changes at all-it simply switches the mailbox address but not the production activities of the firm. This confusion suggests that the Kerry campaign was not completely clear about the so-called tax incentives for outsourcing that it would address.

In the end, Kerry proposed eliminating the deferral of corporate tax on some overseas earnings of U.S. multinationals. Unlike many other advanced economies, the United States taxes the worldwide profits of American firms; many other countries tax only the earnings made within their national territory. The U.S. tax code provides firms with credits for foreign taxes, but this still means that a U.S. firm will pay no less than 35 percent (the U.S. corporate tax rate) on overseas income, paying tax to the source country at its tax rate and paying the balance to the United States. This puts U.S. firms at a disadvantage compared to many of their foreign competitors in jurisdictions with corporate taxes below 35 percent. To partially offset this tax disadvantage, U.S. firms are generally allowed to defer paying tax on overseas income until it is repatriated to the United States. 
The Kerry proposal would have eliminated this deferral for income on goods made in a foreign country and sold to the United States or to a third country. Income on goods made overseas and sold within the same country would still be eligible for deferral. Administering the proposal would have been complex, since it would have been necessary to track the goods to see if they eventually left the country in which they were produced.

In contrast, the economic effects of the proposal were fairly simple. To the extent that deferral was eliminated, U.S. firms would face a higher tax rate than many of their foreign competitors, and would thus be at a disadvantage in jurisdictions with lower corporate tax rates than the United States (which includes most advanced economies). For example, a U.S. firm manufacturing computers in Ireland and selling them in Germany would have faced higher taxes than a German or French company selling computers in Germany. At the same time, it is unlikely that the proposal would have done much to stop the supposed transfer of U.S. jobs overseas. As discussed below, nearly 65 percent of the production by U.S. multinationals' foreign affiliates is sold in the country of production, and this income would not have been affected by the proposal (since profits from sales in the country of production would still benefit from tax deferral). Ironically, any success in imposing a heavier tax burden on U.S. firms would have encouraged inversions that take firms' overseas income outside the U.S. tax base.

To the extent that more of U.S. firms' foreign source income was subject to an immediate instead of deferred tax, this would likely have led to job losses not gains in the United States. The weight of empirical evidence, discussed in more detail below, suggests that increased employment by U.S. multinationals in foreign subsidiaries leads to increased employment at their U.S. locations. That is, on balance, firms do not shift jobs from the United States to overseas (though some particular jobs certainly are shifted in this way), but instead create jobs in the United States when they add them overseas. While job creation is not necessarily the best metric on which to judge economic policy (even if it felt that way in 2004), economic research so far thus implies that deferral of foreign-source income does not lead to a loss of jobs overseas in the first place, and that 
proposals to end it would likely lead to near-term job losses by U.S. firms in both their domestic and foreign affiliates. With the weak labor market largely unconnected to outsourcing in the first place, the Kerry proposal was essentially a bad idea aimed at a problem that did not exist. Nonetheless, it remained a regular staple of Senator Kerry's blasts against outsourcing.

\section{Paul Samuelson's (Misdirected) Salvo against Outsourcing}

As shown in Figure 1, outsourcing surged back into the news in the period just before the election. In part, this reflected the intense focus on the issue in Democratic campaign ads in the battleground industrial states such as Ohio. An additional focus of coverage on outsourcing followed a September 9, 2004 article in the New York Times that reported on a remarkable new paper by Nobel Prize-winning economist Paul Samuelson (2004) that purported to cover outsourcing. The article in the Times informed readers that:

In an interview last week, Mr. Samuelson said he wrote the article to "set the record straight" because "the mainstream defenses of globalization were much too simple a statement of the problem." Mr. Samuelson, who calls himself a "centrist Democrat," said his analysis did not come with a recipe of policy steps, and he emphasized that it was not meant as a justification for protectionist measures.

BusinessWeek (December 6, 2004) well summarized many people's (mis)interpretation of the Samuelson article:

So unprecedented, so colossal, and so fast is this change [in the world economy] that eminent economists such as Paul A. Samuelson are beginning to question the basic tenets of free-trade theory. Is it possible that David Ricardo's economic analysis doesn't work for the 21st century? Can the theory of comparative advantage operate when China and India compete not only with low-cost labor but also with highly educated, highly skilled workers who have access to broadband and the Internet? What is the U.S. supposed to 
specialize in when Asia competes across the board in manufacturing and services in both low-end and high-tech jobs? Is the future prosperity of America in jeopardy?

BusinessWeek answered the final question in the negative, but many with the opposite view embraced Samuelson's contribution as intellectual support, without understanding what it really said. The headline of the Pittsburgh Post-Gazette on September 23, 2004 put the reaction succinctly: "Nobelist Samuelson says Outsourcing May Not Be a Plus."

Samuelson's paper, which was eventually published in the Summer 2004 issue of the Journal of Economic Perspectives, showed that technical progress in a developing country such as China had the potential to reduce welfare in the United States. As the above quotations illustrate, outside the economics profession, this work was viewed as providing a rebuttal to those who had claimed that trade, globalization, outsourcing, and related phenomena would benefit Americans. The idea that this was a rebuttal appears to have been spurred by Professor Samuelson himself in discussions with journalists (as recounted in turn to us). The actual point of the paper, however, was that changes in China that led to less trade would lower U.S. welfare-a development that came about because the United States was losing some of the benefits it derived from free trade in the first place!

As explained by Bhagwati, Panagariya, and Srinivasan (2004) and in more detail by Panagariya on his website, Samuelson's paper involved three stages. First, starting from autarky, China and the United States open up to trade and experience the usual benefits of trade based on comparative advantage. Second, China has a productivity gain in its export good, which improves the U.S. terms of trade and further benefits the United States. Samuelson's third stage (or second "Act" as he put it) involves a Chinese productivity gain in its import good. This narrows the differences between the countries and thus reduces the scope for trade, potentially so much that all trade disappears. As trade diminishes, so too do the gains from trade. 
As Panagariya points out, the potential for productivity changes to reduce the gains from trade has long been understood (Panagariya has Harry Johnson teaching this at the University of Chicago in the 1950's). The harm in Samuelson's setup comes from having less trade, not more. This is light-years removed from the usual concerns of people about globalization giving rise to too much economic integration, not too little. Dixit and Grossman (2005) further point out that the U.S. terms of trade if anything has improved since 1990, rendering moot even Samuelson's theoretical scenario. And in any case, all of this has nothing to do with outsourcing, despite strained interpretations of such by Samuelson.

The underlying substance was largely lost in media discussions of Samuelson's paper. One possible reason is that the Journal of Economic Perspectives published Samuelson's cryptic paper by itself and then the explanation and gentle rebuttal by Bhagwati, Panagariya, and Srinivasan only later, in the Fall 2004 issue. This issue of the journal, however, came out after the November election, when media attention to outsourcing had fallen off from the pre-election peak.

\section{How to Communicate: Choosing Words with Care}

Even before offshore outsourcing became a focal point in the political debate, it was an issue for the business community. Executives at a large number of U.S. companies had to explain why they were expanding operations abroad while the U.S. economy was mired in recession and many Americans were looking for work. The Business Roundtable (BRT), an association of CEOs of leading U.S. companies, took up the task of developing a communications strategy (enlisting, ironically, the input of a Democratically-affiliated media firm). The main consumers of the BRT communications strategy were the association members, who had to defend their "Benedict Arnold" business plans. But representatives of the BRT shared their conclusions with many in Washington, including some members of the Bush Administration. 
Table 1 reproduces a table from a presentation of the BRT communications strategy. To professional economists, this "analysis" seems vaguely comical. But it does contain an important reminder to those whose jobs require speaking about economic matters to the broad public, most of whom have never taken a single course in economics. The explicit meaning of words matter, but tone and subtext matter just as much, and perhaps more so.

A good example is the word "protectionism." To economists, this word has distinctly negative connotations. It makes us think of the $18^{\text {th }}$-century mercantilists that Adam Smith refuted, the corn laws that David Ricardo campaigned against, and the Smoot-Hawley tariffs that exacerbated the hardships of the Great Depression. To a noneconomist, however, the word sounds very different. The root of the word is "protect," and in many ways that is precisely what the government is supposed to do. The government's job is to maintain a military to protect us from foreign invaders, a police force and court system to protect us against criminals, and a fire department and other agencies to protect us against a variety of disasters. So why shouldn't the government protect us from foreign competition?

Of course, the economics profession has a good answer to this question. But the standard answer does not fit on a bumper sticker. The case for free trade is in fact quite subtle, based on an entire general equilibrium view of how economies function. As Paul Krugman (1994) puts it in his insightful essay, "Ricardo's Difficult Idea," the root cause of the communications problem is the "implicit assumptions that underlie the most basic Ricardian model, assumptions that are justified by the whole fabric of economic understanding but are not at all obvious to non-economists."

What the BRT communications strategy recommends is to avoid the word "protectionism" and to use instead the word "isolationism." This is sound advice. The explicit meanings of the two words may be much the same, but the tone and subtext are very different. While a person may instinctively want to be protected, no one wants to be isolated. To the broad public, the phrase "economic isolationism" conveys the meaning 
of the term "protectionism" better than does "protectionism" itself. So if we need a bumper-sticker version of Ricardo's theory of comparative advantage, it is "Don't Retreat to Economic Isolationism!"

\section{How to Communicate: The Jobs Issue}

In the public's mind, the issue of trade is inextricably linked to the issue of job creation. Embracing free trade is sometimes seen as indifference to the goal of full employment. Although Adam Smith demolished the intellectual case for mercantilism more than two centuries ago, that theory still approximates how most non-economists think about the issue. According to the public's worldview, exports are good, because they create jobs, and imports are bad, because they allow foreigners to steal our jobs.

Politicians have an instinctive reaction to this situation: they adopt the public's mercantilist mindset. This is true of both protectionists and free traders. The protectionists complain that imports are taking jobs away from our workers. The free traders speak about opening markets abroad so we can export more. It is rare to find a politician saying a nice word about imports.

Economists understand that international trade is not, fundamentally, about job creation. An open economy can just as easily be fully employed as an autarkic one, and by realizing the gain from specialization and trade, it will have higher real wages and living standards. Moreover, exports and imports go hand in hand, so when a nation blocks imports, real exchange rates will adjust so it exports less as well. These are subtle lessons, however, and not easily explained in a short sound bite.

When discussing trade policy with the general public, economists must be sensitive to the mythical tradeoff between trade and job creation. One good rule-ofthumb, when asked about trade policy, is to begin the answer by expressing concern about workers displaced by trade and emphasizing the importance of full-employment as a policy goal. This approach can seem unnatural to an economist: because theory and 
evidence indicates that there are net benefits to free trade, it feels strange to start a discussion by emphasizing the downside. The advantage of this approach, however, is that it establishes common ground with the skeptics, before rejecting their conclusions. The economist speaking to the public needs to say, "Yes, I acknowledge the costs of trade that concern many people, but these costs are outweighed by much larger benefits."

\section{Table 1: Words Matter}

$\begin{array}{ll}\text { Words to lose } & \text { Words to use } \\ \text { Competition } & \text { Growth } \\ \text { Retool } & \text { Re-make } \\ \text { Protectionism } & \text { Isolationism } \\ \text { World trade } & \text { Working with the world } \\ \text { Long term growth } & \text { Sustained growth } \\ \text { Global trade } & \text { Trade } \\ \text { Cheaper } & \text { Specialized } \\ \text { Forced to } & \text { Take charge } \\ \text { Cost efficiencies } & \text { Meeting customers' needs } \\ \text { Making our budget } & \text { Meeting our needs } \\ \text { Do more with less } & \text { Do more with more }\end{array}$

Source: The Business Roundtable

\section{Economics: What Do We Really Know About Offshore Outsourcing?}

Facts did not play a focal role in the public debate over outsourcing discussed above. In part, this reflects the reality that there is a lot that is just not known about outsourcing, both qualitatively and, especially, quantitatively. The missing data include even basic information such as a reliable count of the number of jobs that have been subject to offshore outsourcing in the past; see GAO (2004). The difficulty of assessing the extent and impact of outsourcing has left an information gap to be filled by the likes of Mr. Dobbs. The sections below discuss data that help to characterize outsourcing, 
along with empirical analyses on the magnitude of offshore outsourcing and its impact on the economy and the labor market.

\section{How much outsourcing so far? Private Sector Guesstimates}

Media reports in 2003 and 2004 paid a good deal of attention to private sector estimates that a large number of jobs had already been transferred overseas and that many more would be leaving in the years ahead. Probably the most widely-cited such figure was from Forrester Research, which estimated that a cumulative total of 830,000 U.S. jobs would be moved offshore by the end of 2005, and that a total of 3.4 million additional U.S. jobs would move overseas in the decade through the end of 2015 (these numbers are from Forrester's May 2004 update of a November 2002 report). Other forecasts of the number of jobs lost to date to other countries were of roughly the same magnitude as Forrester's estimate of nearly 30,000 jobs per month to be offshored in the future. Goldman Sachs, for example, calculated that about 10,000 jobs per month had moved overseas in the three years before 2004, and that between 15,000 and 30,000 jobs would be offshored going forward. ${ }^{7}$ As a small irony, Forrester's May 2004 projections were slightly increased from their November 2002 estimates because, as the industry publication Computerworld put it: "the political furor has 'increased the awareness of offshore outsourcing, and increased the awareness of the value of offshore outsourcing,' said Forrester analyst Stephanie Moore.”

These estimates of jobs lost to outsourcing were blown far out of proportion to their economic magnitude, which is actually quite small compared to the size of the U.S. labor market and its normal ebb and flow. As Baily and Farrell (2004) note, losses of even 30,000 jobs per month are tiny compared to the two million or more job changes that occur routinely in a single month in the United States: even at the height of the economic expansion of the late 1990's, nearly 100,000 workers per month lost their jobs in mass layoffs. The forecast of 3.4 million jobs to be sent overseas by 2015 likewise

\footnotetext{
${ }^{7}$ As noted by Jensen and Kletzer (2005), these estimates include both services and manufactures.
} 
seems modest compared to the more than 160 million jobs projected by the Bureau of Labor Statistics (BLS) to exist by 2015, and small even compared to the 35 million net new jobs gained over the past decade. And these 35 million new jobs were themselves the net result of much larger gross numbers of jobs gained and jobs lost.

\section{Official Statistics Related to Offshore Outsourcing}

Several official statistical sources provide imperfect evidence on the extent of offshore outsourcing.

\section{Mass Layoff Data}

Perhaps the most direct statistical data come from the Mass Layoff Statistics program of the Bureau of Labor Statistics (BLS), which added questions on job loss related to the movement of work starting in January 2004; these data are described by Brown (2004). The BLS uses filings for unemployment insurance to identify firms that had layoffs involving more than 50 workers out of work for more than 30 days. These firms are then asked whether the layoff involved moving workers to a different geographical location within the company, whether the layoff involved moving work that was previously performed in-house to a different company, and the destination for any relocation (the state if domestic or the country if overseas). This information is provided as part of the quarterly releases on extended mass layoffs.

The results are striking: offshore outsourcing is negligible in the Mass Layoff data. Out-of-country relocations, whether within a company or to a different company account for only 1.6 percent of job separations in mass layoffs over the first six quarters for which data became available (2004q1 to 2005q2). Separations involving relocation of jobs within the United States account for 3.3 percent of separations in extended mass layoffs; the vast majority of job losses do not involve any relocation of work at all. 
Yet these data have several shortcomings that make their lack of evidence for offshore outsourcing inconclusive. The specific questions on the destination for relocation are addressed only to firms that have mass layoffs lasting for more than 30 days (which the BLS states covers only about one-third of all mass layoff events), and mass layoffs in the first place do not cover layoffs of less than 50 workers. As Schultze (2004) notes, the Mass Layoff data likewise do not capture the possibility that firms might reduce hiring as a result of outsourcing, or move work without involving layoffs. It is also possible that firms could assign another reason for separations even when the outsourcing played a role.

\section{BEA Data on Employment by U.S. and Foreign Multinational Corporations}

Data from the Bureau of Economic Analysis (BEA) on the activities of U.S. and foreign multinational corporations provide less direct but still suggestive information on the extent of offshore outsourcing. The BEA measures the activities of U.S. multinationals, including revenues, investment, trade flows, and wages and employment at both overseas affiliates and U.S. firms' domestic operations. The BEA tracks as well the U.S. activities of foreign multinationals; job creation by these firms in the United States has come to be known as "insourcing." As shown below (Figure 2), foreign firms' employment of Americans picked up in the late 1990's before falling off with the U.S. slowdown in 2000 and 2001. 
Figure 2: Employment: Outsourcing and Insourcing

(Millions)

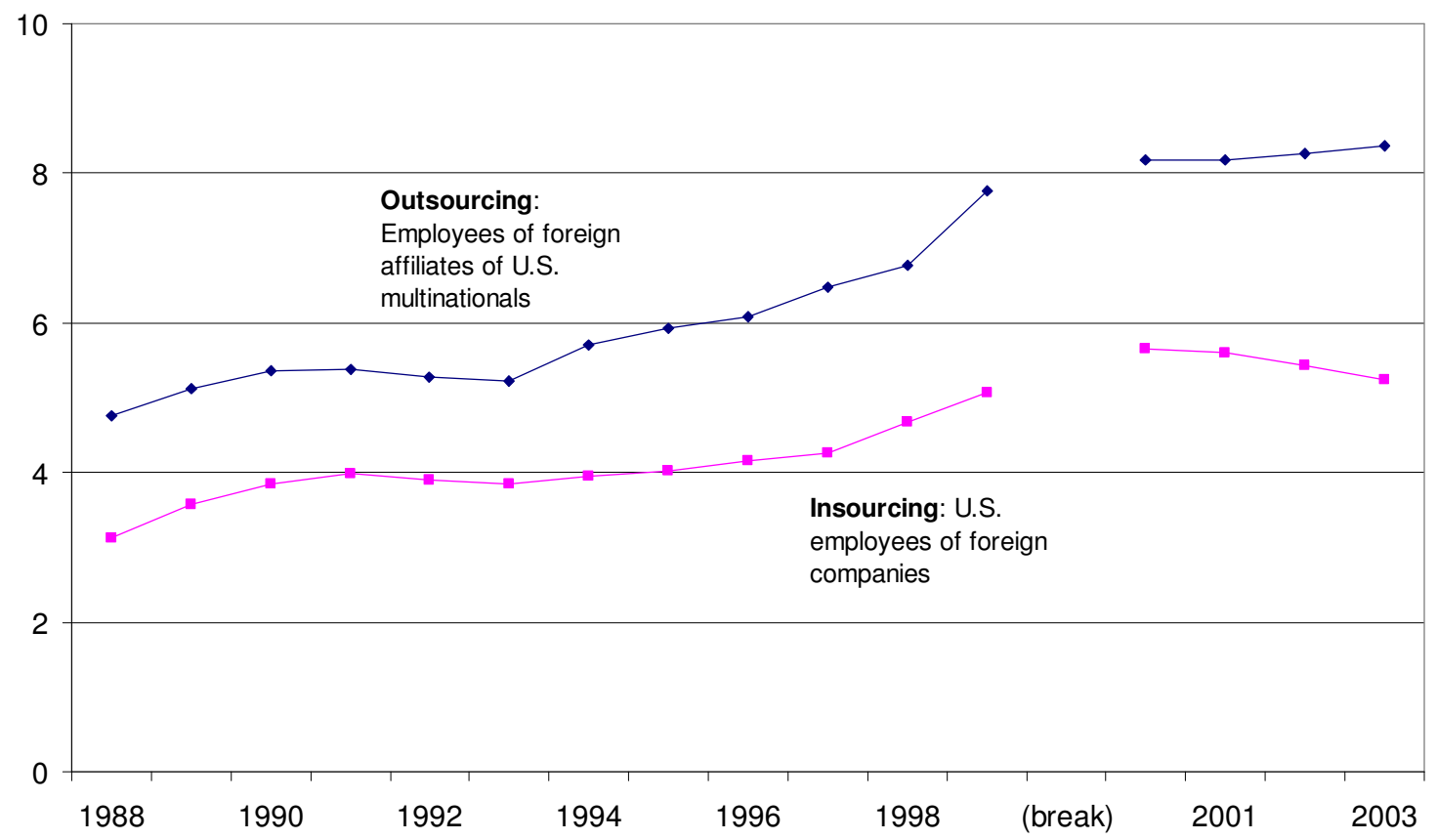

These data have been widely used in research studies. Borga (2005), Hanson, Mataloni, and Slaughter (2003), and Landefeld and Mataloni (2004) use the BEA data to assess the characteristics and evolution of U.S. firms' overseas activities in both manufacturing and services, while Kozlow and Borga (2004) look directly at the growth in U.S. services trade and services trade within the components of U.S. multinational firms for the period from 1992 to 2003.

An important caveat with the BEA data is that while there is information on the number of workers employed by U.S. firms overseas, it is not possible to know how many of these positions represent jobs that formerly existed in the United States and were moved overseas, or are jobs that would have existed in the United States but for the ability of firms to locate production across countries. Unlike the BLS Mass Layoff statistics, the data collected by BEA do not link job changes in the United States with relocations - there is no information collected on the underlying reasons for U.S. firms' decisions regarding the location of expansion and job creation. 
This missing information would be important in distinguishing between overseas expansions that substitute for U.S. employment, and activities that complement U.S. job gains. It could be that hiring workers overseas allows a U.S. firm to expand U.S. employment, or even that a U.S. firm would shut down but for the ability to lower costs through offshore outsourcing. In this latter case, outsourcing could be said to save rather than destroy jobs in the United States. The BEA data shed only indirect light in distinguishing between these possibilities. Nonetheless, the BEA data are today essentially the only solid numbers on the activities of U.S. multinationals.

Domestic employment by U.S. multinationals declined during the period of the weak labor market from 2001 to 2003 (the last year for which data are available as of March 2006) (Figure 3). Employment growth at U.S. firms' foreign affiliates slowed but did not retreat. It is impossible to tell directly, however, whether the foreign job gains replaced U.S. jobs, or instead whether this reflected the divergence of global growth experiences. In the latter case, U.S. firms might have continued to hire overseas to serve local markets growing faster than the United States. This possibility would be consistent with the empirical finding that nearly all of the output of U.S. firms' foreign affiliates is sold abroad rather than in the United States. The decline in employment in the United States at majority-owned affiliates of foreign companies shown in Figure 2 suggests a common business cycle explanation of employment losses related to the slowing U.S. economy. 
Figure 3: Employment by U.S. Multinationals

(Millions)

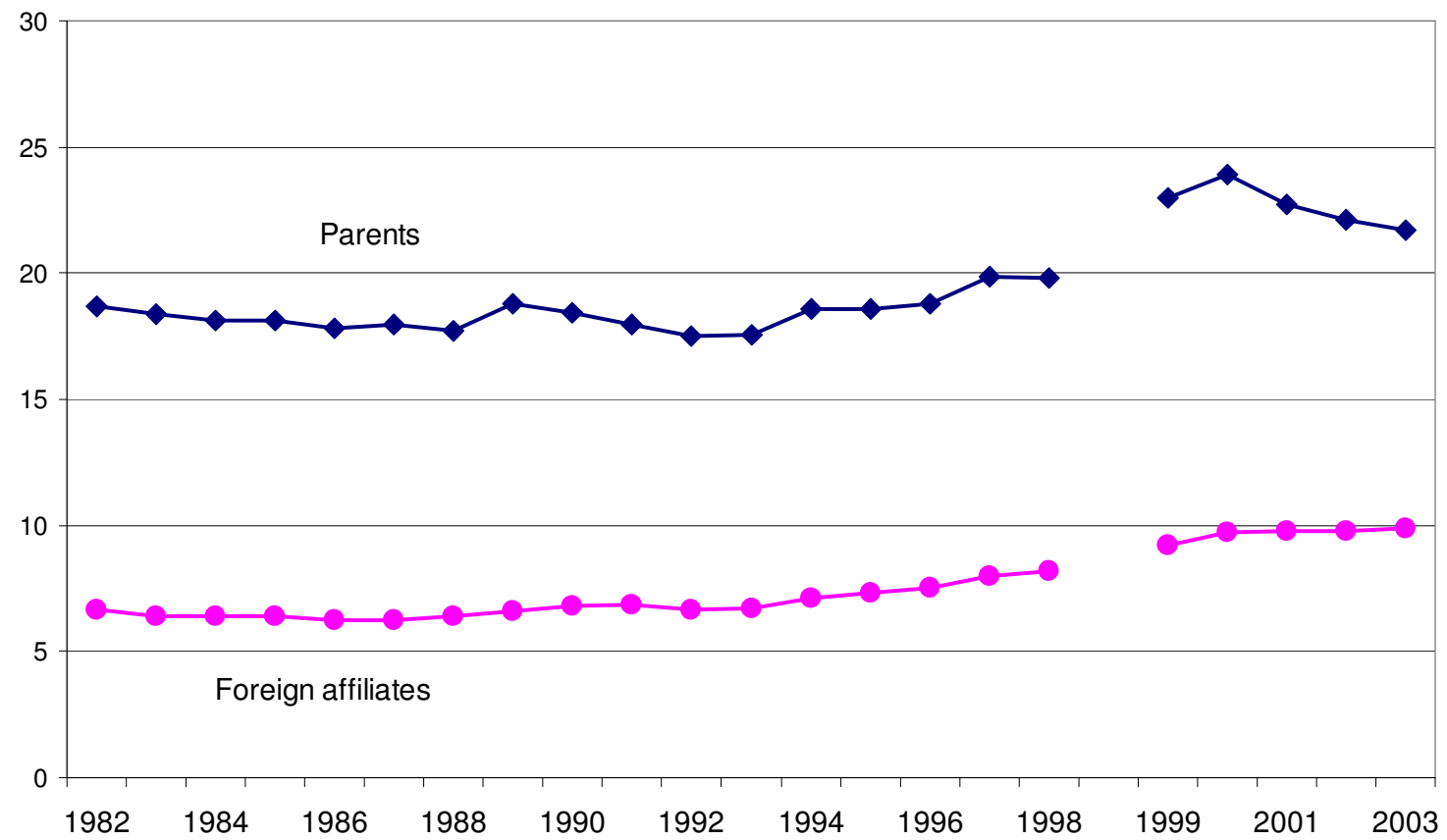

Moreover, there is evidence that increased activity and employment by overseas affiliates of U.S. multinationals is associated with increased employment and activity in the U.S.-based parents. Hanson, Mataloni, and Slaughter (2003) examine the substitutability between domestic and foreign workers of U.S. multinational firms. They use firm-level data on sales, employment, wages, tax rates, and other variables to estimate labor demand equations for U.S. multinationals. The results indicate that higher sales in foreign affiliates leads to increased labor demand in U.S. parents-success overseas leads to job gains in the United States. While total U.S. employment by multinationals increases with expansion overseas, the jobs gains are not evenly distributed across different types of workers: high-skilled foreign workers are complements with U.S. workers, while low-skilled foreign workers are substitutes for them. This means that as skilled workers at overseas affiliates become less costly, U.S. multinationals use more labor in their U.S. parent locations. Improved technology and telecommunications that makes it less expensive to employ skilled workers in other countries - radiologists in India, for example — would be expected to lead to job creation in the United States. By contrast, lower wages for low-skilled workers in other countries 
would lead to less labor demand at U.S. parents. This latter result differs from Brainard and Riker (1997), who found that U.S. parent employment over 1983-1992 responded little to changes in wages at foreign affiliates.

Desai, Foley, and Hines (2005) provide further evidence that foreign activity by U.S. multinationals complements rather than substitutes for domestic activity by the same firms. The paper uses affiliate-level information on U.S. manufacturing firms from 1982 to 1999 , matching individual foreign operations to domestic activities of the same firms. They find that an additional $\$ 10$ of foreign capital investment is associated with $\$ 15$ in additional domestic investment, and that \$10 in additional foreign employee compensation is associated with $\$ 18$ in additional domestic employee compensation. As with Hanson, Mataloni, and Slaughter, foreign activity does not crowd out domestic; the reverse is true.

Borga (2005) quantifies changes in U.S. firms' imports of goods and services from their overseas affiliates from 1994 to 2002, and examines the relationships between these imports and variables such as employment. She shows that activities associated with outsourcing are neither quantitatively large nor have they increased markedly in recent years. As Lawrence (2005) notes, Borga's empirical approach provides information on relationships between the variables two at a time (between services imports and employment), but does not reveal conditional correlations such as how imports affect employment while controlling for other factors affecting the demand for offshoring or the state of the labor market. Borga likewise does not provide information on the causal relationships between outsourcing and firm activities. With these caveats in mind, the results still provide interesting information. Services imports by U.S. multinationals represent only a small part of parents' total purchases of goods and services in the first place_-less than one-half percent—and actually declined from 0.4 percent of parents' purchases in 1994 to 0.2 percent in 2002. At least for activities performed within the confines of U.S. multinationals, offshore outsourcing of services cannot have been a meaningful contributor to overall job losses during this period of rapidly expanding global economic integration. Borga further shows that offshoring of 
goods would not be expected to matter much for job growth either, as goods imports from overseas affiliates of U.S. firms grew modestly (from 3.5 percent of parent company purchases to 4.6 percent), while the share of goods imports from non-affiliated firms was flat.

Landefeld and Mataloni (2004) provide further suggestive evidence that offshore outsourcing played only a modest role in the U.S. labor market from 1989 to 1999 (which, as shown in Figure 2, is a period in which U.S. multinationals' foreign employment increased markedly). They find that outsourcing increased substantially over this ten year period, just not offshore outsourcing: purchases of intermediate goods and services by U.S. multinationals rose as a share of sales from 1977 to 2001 but purchases of imports as a share of parents' sales did not rise by much and actually decreased since 1998. This suggests that overseas expansion by U.S. multinationals has not been aimed at supplying the home market.

Landefeld and Mataloni likewise find that overseas expansion by U.S. multinationals in the 1990's does not seem to have displaced U.S. hiring by these firms, as domestic job creation by multinationals expanding overseas was little different from job creation by all U.S. firms (1.6 percent annual average job growth in multinationals compared to 1.8 percent in overall U.S. employment). It is possible, of course, that multinationals would have expanded even faster in the United States had it not been possible to hire overseas. Again, however, the data on imports suggests that any activity displaced from the United States was aimed at supplying overseas markets.

This is confirmed by Landefeld and Mataloni's data showing that by far the largest part of the output by U.S. multinationals' overseas operations is sold in foreign markets. Only 11 percent of the total output of U.S. firms' foreign affiliates goes to the U.S. market. Instead, 65 percent goes to the local market - the same country as the affiliate-while another 24 percent goes to third party foreign markets. Moreover, overseas affiliates are quite profitable, contributing to U.S. profits at on average twice the rate of firms' domestic U.S. operations. These numbers highlight the contradictions of the 
Kerry tax plan: the idea that U.S. firms are shipping products back to the United States and disrupting the U.S. labor market simply does not line up with the data.

The BEA data also suggest that the extent of outsourcing to low-wage countries is less than one might infer from media reports. U.S. firms' overseas operations are carried out mainly in other advanced economies, rather than in developing nations. Mataloni (2005) finds that Canada, the United Kingdom, Germany, Mexico, and Japan were the top host countries for majority-owned foreign affiliates of U.S. multinationals in 2003. There is evidence, however, that recent overseas expansions are weighted toward other economies. While Landefeld and Mataloni state than more than 60 percent of U.S. multinationals' overseas jobs are in high-wage countries, overseas employment growth has been especially strong in low-wage countries such as Mexico, Poland, China, India, and Malaysia. They further find that U.S. multinationals pay lower wages to their overseas employees than to workers at their U.S.-based parent, but cannot control for differences in occupations or worker characteristics.

Finally, Landefeld and Mataloni provide evidence consistent with an impact of offshoring on U.S. job creation in certain sectors. Overseas job growth was especially strong in foreign affiliates of U.S. firms providing computer and data processing services, with overseas employment gains of 22.4 percent from 1989 to 1999 compared with job growth of only 6.8 percent at U.S. parents. Accounting and auditing services, and engineering and architecture services likewise added jobs overseas (10.9 percent and 7.3 percent growth, respectively) far stronger than in their U.S. locations (parents in accounting had average annual job gains of only 0.6 percent while those in architecture lost 0.6 percent of jobs on average each year from 1989 to 1999). In these three sectors, domestic employment growth of multinationals also lagged behind overall U.S. employment growth (that is, including the non-multinationals), suggesting that multinational behavior was different from other firms and not simply a reflection of cyclical factors. In contrast, legal services and research and development services were industries in which employment in U.S. firms' overseas affiliates grew faster than in the 
U.S. parent, but multinationals still added jobs in these sectors in the United States faster than non-multinationals.

Mann (2005) provides related evidence that offshoring affects the composition of labor within an industry, including changing the mix of skilled workers. Looking at the information technology sector, Mann calculates that about 125,000 programming jobs were lost between 1999 and 2003, but 425,000 jobs were gained for higher-skilled (and generally higher-paying) software engineers and analysts. Over the same period, Mann notes that over 500,000 jobs were lost in services occupations requiring "routinized tasks," such as telemarketers and data entry—about one-third of the jobs in those occupations in 1999.

\section{Gleaning Information on Outsourcing from Data on Trade Flows}

A number of efforts have looked at the implications of trade data for employment changes. Broadly speaking, the idea is that imports and exports embody factors of production, so that increased imports of business services might be seen as an indirect way to measure employment changes related to offshore outsourcing.

In the trade data compiled by the Census Bureau, outsourcing would be expected to be found within the category of "Business, Professional, and Technical Services," (BPT) which is a part of "Other Private Services"- the "other" is because this category excludes the large categories of services trade in royalties and license fees, and travel and related items such as passenger fares. Business, Professional, and Technical Services (BPT) includes trade in computer and information services, management and consulting services, research and development and testing services, operational leasing, and an “other" category. Trade in BPT does not include education, financial services, insurance, and telecommunications, which are included along with BPT in the broader category of "Other Private Services." Education, finance, insurance, and telecoms would not be expected to fall under the rubric of outsourcing, which more commonly refers to business 
services such as call centers and professional services such as engineering design or radiological diagnoses (both of which fall under BPT).

The United States has a large and growing trade surplus in business, professional, and technical services (Figures 4 and 5). U.S. imports of business, professional, and technical services equaled $\$ 40.7$ billion in 2004 , or just under 16 percent of total private services imports. These imports have nearly doubled in the 7 years since they began to be separately tracked in 1997, and are up from 13.7 percent of total services imports in 1997. Still, BPT represents only about 2 percent of total imports of goods and services (Figure 6), and imports of BPT services actually declined slightly as a share of total services imports from 2003 to 2004. Exports of business, professional, and technical services equaled $\$ 75$ billion in 2004, which was 22 percent of total private services exports and just over 6 percent of total U.S. exports of goods and services in 2004. Exports of business, professional, and technical services are up by 62 percent since 1997, and from a larger base than imports, meaning that the U.S. trade surplus in BPT expanded over the seven years (Figure 4).

Figure 4: U.S. Trade Balance in Business, Professional, and Technical Services, \$bn

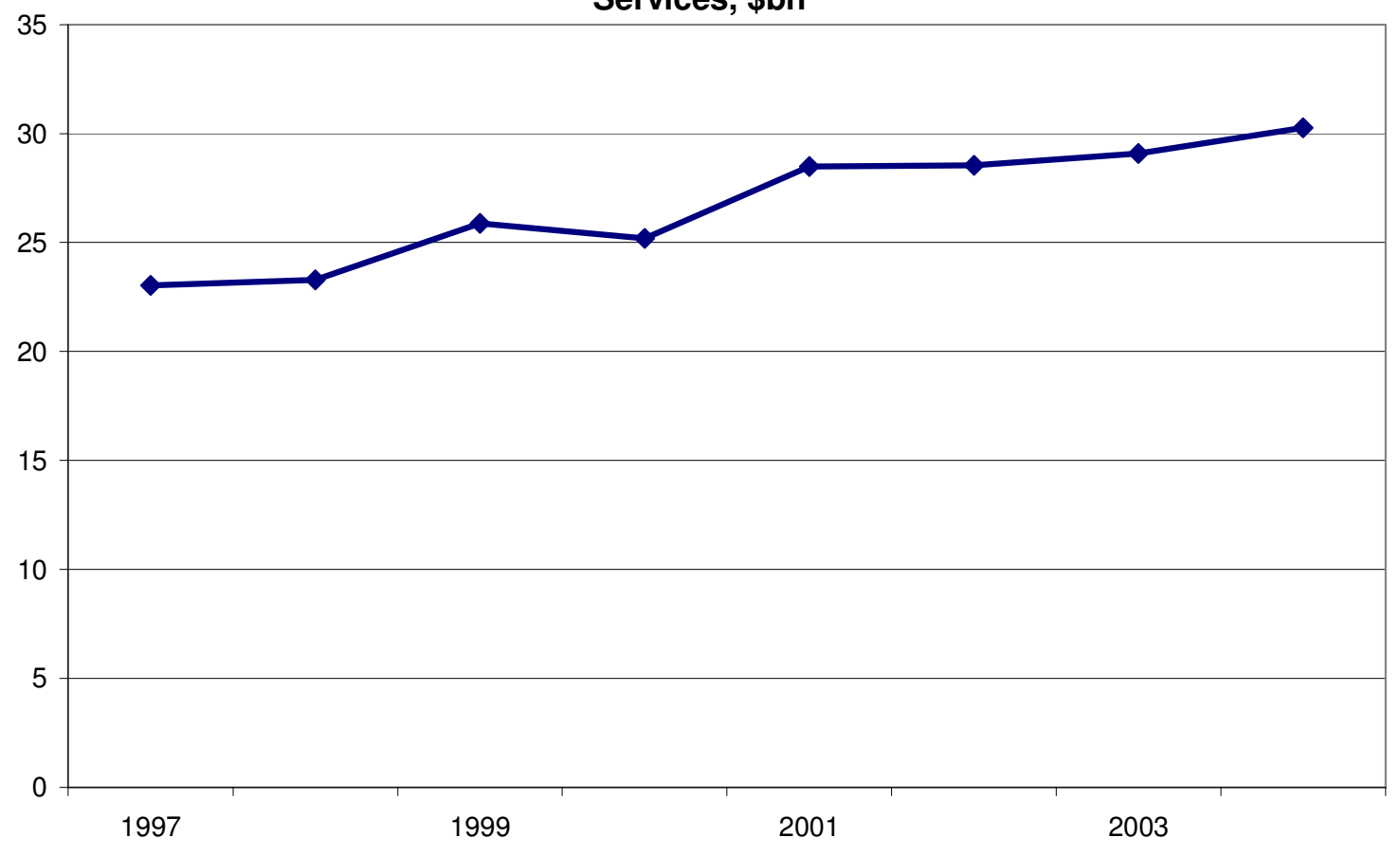


Figure 5: U.S. Trade in Business, Professional, and Technical

Services, \$bn

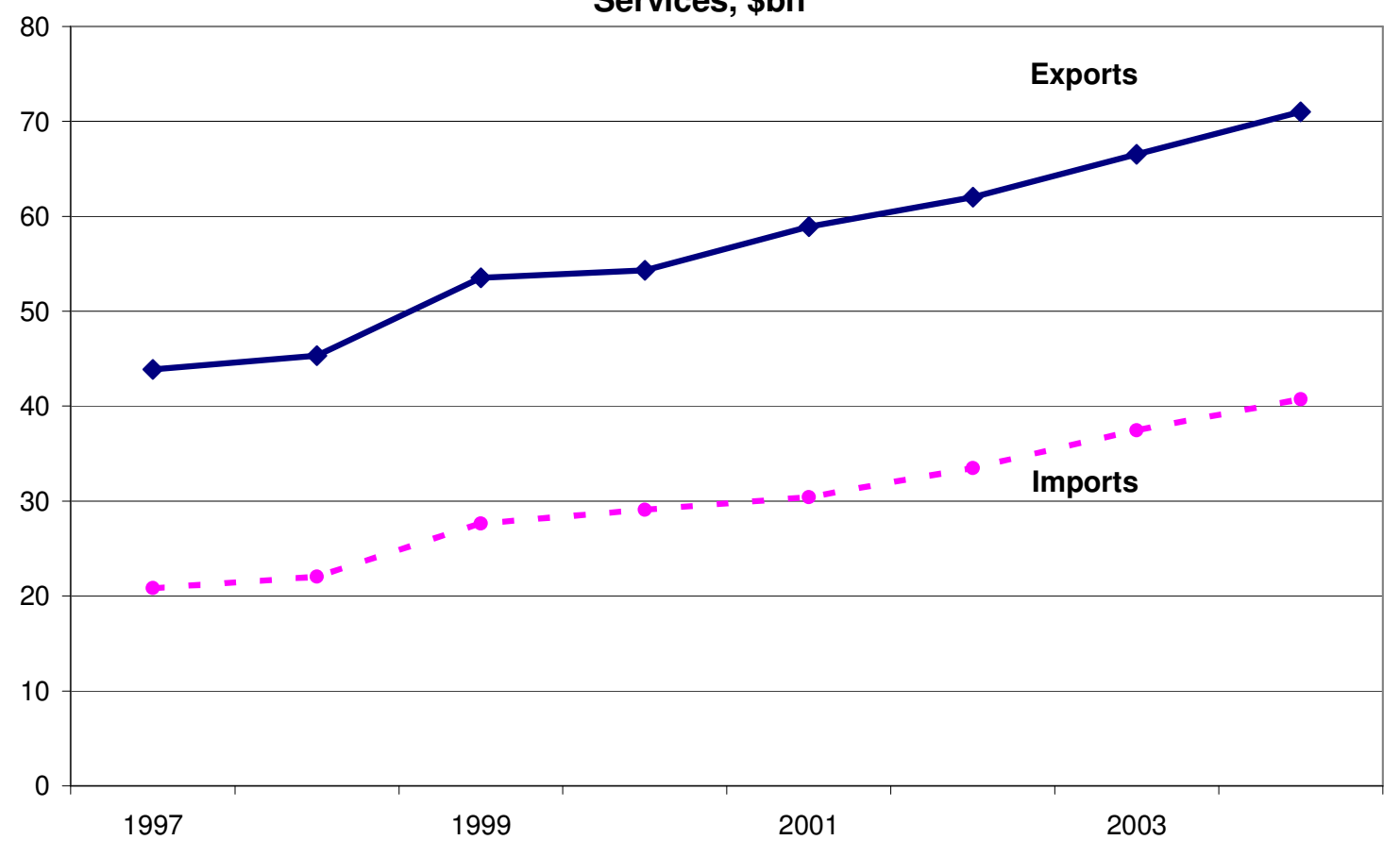

The trade category that includes outsourcing is small compared to U.S. trade in goods or even compared to U.S. trade in services such as travel and transportation-and much smaller than total trade in goods and services (Figure 6). Still, the data suggest that business, professional, and technical services is a type of trade at which the United States has a comparative advantage - that is, we will likely be better off if there is more rather than less trade in business services. This is especially ironic given that critics of outsourcing such as Senator Schumer worry that comparative advantage no longer applies in the modern world economy. 
Figure 6: U.S. Trade Flows, Overall and Business Services, \$bn

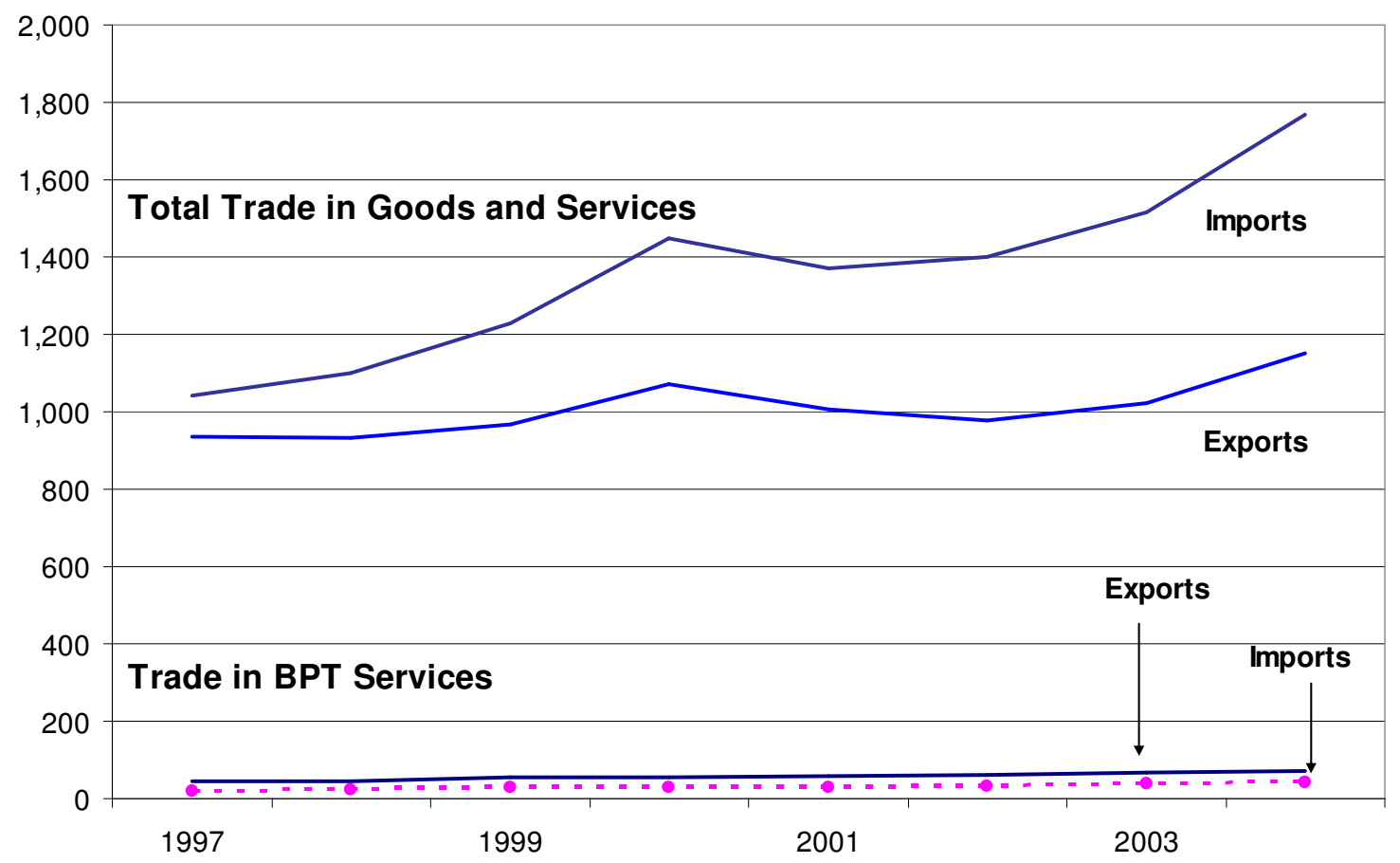

Kozlow and Borga (2004) examine more detailed aspects of the data on trade in other private services and in the subcategory of business, professional, and technical services. Within other private services, they note that both imports and exports grew rapidly from 1992 to 2003, with the surplus in other private services continuing to widen even while the overall U.S. trade surplus in services narrowed. The pattern of trade among trading partners is noteworthy. Stepped up U.S. services imports from Asian economies such as China, Hong Kong, and India outpaced declining imports from Taiwan, a phenomenon that points to a possible product cycle as trade in services matures and moves from high-cost to lower-cost countries.

Kozlow and Borga note that the BEA data on U.S. services imports account for little of the services exports to the United States reported by other countries. For example, the BEA import data capture only 17 percent of 2002 services exports from India to the United States, as reported by India. It is unclear the extent to which the U.S. data understate these trade flows or the Indian data overstate them. Even much larger numbers 
for U.S. services imports, however, would matter little for calculations of GDP. Moreover, if services imports are higher than reported in the U.S. data, then exports are likely understated as well.

In sum, direct data on U.S. trade in the services most connected with offshore outsourcing show that the United States is importing more of these business, professional, and technical services than in the past. At the same time, however, the United States is exporting even more - and the U.S. trade surplus is growing not shrinking. There are both winners and losers from the trade flows, but the most meaningful data on trade in services indicate that, on the whole, improvements in technology and telecommunications that have made services increasingly tradable have presented an opportunity for the United States.

Several other studies have used trade data to calculate the job flows implicit in U.S. goods and services imports or in U.S. net exports. Schultze (2004) calculates that rising services imports from 1997 to 2001 accounted for a loss of perhaps 55,000 to 70,000 jobs per year, a number too small to play a meaningful role in driving the recent weak labor market (which he attributes largely to the temporary impact of strong productivity growth). Schultze further calculates that even the most extreme estimate of the number of jobs transferred to foreign affiliates from 1999 to 2001 was 180,000 per year, or only 0.16 percent of private employment.

Baily and Lawrence (2004) examine the broad impact of imports on U.S. employment, and then focus in on the impact of offshore outsourcing of services in particular. They find that the impact of service sector offshoring to India over 2000 to 2003 was small compared to the overall change in service sector employment. Along the lines of Mann (2005), they find that lower level programming jobs were lost to India but overall computer employment was surprisingly strong. And rather than decrying these changes, they provide evidence that services offshoring such as to India will raise U.S. GDP and create jobs, including in manufacturing. Baily and Lawrence perform simulations using a large-scale macro-econometric model to assess the impact of 
Forrester's estimate of future outsourcing, which they view as the largest plausible forecast. They find that U.S. GDP, real compensation of employees, and real profits will all be higher in 2015 as a result of lower prices for services imports associated with outsourcing. This is just the usual gains from trade. If offshoring is instead done at today's prices rather than lower prices resulting from using imported services, then the welfare benefits will be smaller as the United States loses the terms-of-trade benefits. But there are still gains from outsourcing.

Baily and Lawrence further use an input-output framework to look at the jobs associated with trade flows and point to weak exports after 2002 rather than rising imports as the source of trade-related job loss. They attribute weak U.S. exports mainly to the lagged impact of the strong dollar from the late 1990's. This is seen as more important than alternative factors such as slow growth of world trade; a concentration of U.S. exports in categories such as technology for which demand grew relatively during the downturn; and the weak growth in the destinations of U.S. exports.

Groshen, Hobijn, and McConnell (2005) similarly use an input-output approach to calculate that the net job loss from trade has been generally modest in recent years, and that job losses attributable to trade actually diminished rather than increased after the recession ended in 2001. They find that the jobs embodied in U.S. net imports corresponded to 2.4 percent of total U.S. employment in 2003, but much less in most other years. And in some years, trade flows correspond to a net gain in U.S. employment, because the analytical framework looks at both job loss and job gain from imports and exports. Moreover, even with the outsized results for 2003, jobs embodied in net imports did not grow faster after the 2001 recession than before, but instead decelerated compared to the pace from 1997 to 2001 when U.S. payroll growth was more robust. In other words, trade flows were not the reason for the weak employment recovery after the downturn.

Amiti and Wei $(2005,2006)$ also find that services outsourcing is small and plays little role in recent employment fluctuations, but possibly plays a meaningful role in 
accounting for productivity growth. Using data for the United Kingdom (2005), they find that sectors with more services outsourcing do not have a slower rate of job growth than sectors without outsourcing. For manufacturing industries in the United States, Amiti and Wei (2006) find that offshoring of services inputs accounts for around 11 percent of firms' productivity gains from 1992 to 2000, but with little impact on employment.

In sum, analysis of direct and indirect data on offshore outsourcing and jobs associated with trade flows indicates that these related phenomena played only a modest role in labor market developments since downward phase of the business cycle began around the end of 2000 or early 2001.

\section{How much outsourcing in the future? Who is vulnerable?}

While the amount of offshore outsourcing so far is fairly small except in the popular imagination, much of the concern over the phenomenon relates to expectations about the future. As discussed by Blinder (2006), an oft-expressed worry is that future workers in previously sheltered parts of the economy will come under competitive pressure from trade made possible by new technologies and improved communications. This competition could cut across sectors and occupations. In addition, even a small amount of actual offshore outsourcing could have a magnified impact on the labor market. This could come about, for example, if the possibility of outsourcing gives employers greater power in their bargaining with workers over wages.

The dislocation from offshore outsourcing might also reduce the value of jobspecific capital, which could in turn reduce the incentives for individuals to invest in specific human capital. With enough dislocation or even potential dislocation, the impact in terms of reduced human capital could be quantitatively large. Not just actual outsourcing, but the threat of it could lead individuals to undertake less training. On the other hand, dislocation from offshoring could provide increased incentives for individuals to invest in general human capital rather than more job-specific knowledge. This could 
actually increase the flexibility and future productivity of advanced economies affected by offshoring. So far, the modest amount of offshore outsourcing suggests that the corresponding costs of dislocation have been small. And these costs must be compared to the welfare gains from increased trade in areas such as services that were previously nontradable.

Suggestive evidence on the potential dislocations from outsourcing can be gleaned from previous work on the labor market impact of other changes such as improved technology. Autor, Levy, and Murnane (2003) find that increased computerization altered demands for job skills. Computers substituted for jobs that could be accomplished by following explicit rules, but were complements to jobs requiring problem-solving and complex communications. As a result, computerization led to reduced labor demand for low-skilled workers, accounting for up to 60 percent of the change in relative labor demand toward college-educated workers from 1970 to 1998. Task changes within nominally identical occupations accounted for almost half of the impact.

Thinking of potential offshore outsourcing to low-wage countries as a flesh-andblood analogue of computerization suggests that more prevalent outsourcing could similarly affect labor demand and returns to skill. As Irwin (2005) notes, however, the types of workers who could come under pressure from international competition range across many different levels of skills. In his example, workers at call centers are probably relatively low-skilled; financial analysts and traders would be expected to have moderate skills; and radiologists are high-skilled. It might be difficult to know in advance the changes in relative demands set into motion by future offshore outsourcing. As usual, understanding whether the United States gains or loses from the ability to undertake trade in new types of services depends on whether or not the new commerce leads to an improvement in the U.S. terms of trade. 
A first step in understanding the possible changes would be to figure out the types of jobs and workers potentially subject to competitive pressure from offshore outsourcing. This is the subject of several analyses.

Bardhan and Kroll (2003) calculate the number of jobs at risk of outsourcing based on the characteristics of jobs. They assume that jobs are potentially subject to outsourcing if they require no face-to-face interaction, have high information content, and involve a work process that can be structured to involve telecommunications or the Internet. They find that about 11 percent of occupations are at risk for outsourcing, about 14 million of 128 million jobs in 2001. Occupations at risk for outsourcing had somewhat higher average annual salaries than overall occupations.

Blinder (2006) divides services into ones that are "personally-delivered" such as a waiter taking an order or a doctor performing a physical exam, and "impersonallydelivered" such as a clerk making a reservation over the telephone. Looking at employment by industry, Blinder sees financial services and information services as the main candidates to join business and professional services in being increasingly subject to outsourcing. He likewise sees some educational activities, notably in higher education, as possibly being outsourced in the future, while jobs in other sectors, including manufacturing, government, wholesale and retail, leisure and hospitality, transportation, and utilities involve more personal delivery and are thus less susceptible to outsourcing. Blinder's calculation leaves about 28 million of the 132 million jobs that existed at the end of 2004 as potentially subject to outsourcing. In considering this, it is useful to note that the United States has a trade surplus in at least some of these "impersonal" services - this is the case, for example, in higher education, where the United States has a large surplus. Other things being equal, increased trade in services such as higher education would be expected to move the U.S. trade balance toward surplus.

Jensen and Kletzer (2005) identify potentially tradable service sector occupations and activities based on spatial clusters. If service providers are clustered together within the United States, Jensen and Kletzer reason that the activities and occupations involved 
must be tradable within the United States, since otherwise the service providers would be more geographically dispersed. Activities and occupations that can be traded within the United States are assumed to be internationally tradable as well. Looking across both occupations and industries, Jensen and Kletzer find nearly 30 percent of total employment to be tradable. Workers in tradable services have higher skills, higher wages and incomes, and higher displacement rates than workers in nontradable service jobs. Even while job security is lower in tradables, Jensen and Kletzer find little evidence of weaker employment growth in tradable activities or occupations than in nontradable ones. Indeed, their results are consistent with the data on U.S. services trade flows that suggest U.S. comparative advantage in the provision of services.

\section{The Impact on Offshore Outsourcing on U.S. Incomes}

As with more familiar forms of trade, offshore outsourcing would be expected to have a mix of positive and negative effects for particular individuals, even while it increases overall U.S. income. Evidence for gains from offshore outsourcing is available from work by the McKinsey Global Institute (2003). The McKinsey study has been widely cited in policy circles, despite the fact that (or perhaps because) it adopts a framework different from the typical approach of an academic economist. In essence, McKinsey approaches outsourcing from the standpoint of a cost-benefit analysis, summing up the gains and losses to the various economic participants affected by it. In the end, they find that the gains from outsourcing outweigh the losses for the United States.

McKinsey's work is based on a mix of interviews with offshore providers in India and numerical analysis on data from India and U.S. statistical agencies. McKinsey analysts interviewed several dozen offshore providers in India, divided them into categories based on the type of service provided, and estimated models of cost saving based on the company interviews and interviews and data from government sources and trade associations in India. McKinsey then combined this information with data on U.S. 
users of outsourced services and BLS employment data to arrive at estimates of benefits and cost savings. McKinsey also estimated the income earned from reemploying displaced labor (calculated using wages from studies of displaced workers), along with some other smaller changes in income.

McKinsey summarizes their cost-benefit calculation for one dollar of outsourcing as follows:

- $\quad$ Savings accrued to U.S. investors and/or customers from lower costs resulting from the use of outsourcing come to $\$ 0.58$.

- $\quad$ Imports of U.S. goods and services by providers in India equal \$0.05.

- $\quad$ Profits transferred by U.S. overseas affiliates to parents equal $\$ 0.04$.

- $\quad$ The value from U.S. labor reemployed is conservatively estimated to be $\$ 0.45$ to $\$ 0.47$.

This gives a total gross gain to the United States of $\$ 1.12$ to $\$ 1.14$ for every dollar of work offshored to India, for a net increase in U.S. income of 12 to 14 cents per dollar of offshore outsourcing. In addition, McKinsey did a similar calculation for India and concluded that India gains a total of \$0.33 for every dollar of U.S. outsourcing.

A study by Global Insight (2005) likewise finds net gains to U.S. incomes, wages, and employment resulting from offshore outsourcing of software development and information technology services.

\section{Why does offshore outsourcing happen? What is the best way to model it?}

Spencer (2005) and Trefler (2005) provide surveys of the theoretical literature on outsourcing, which focuses mainly on firms' decisions to undertake outsourcing. The theoretical literature looks at decisions on whether to split production into a vertical chain, whether to contract for some production activities with an unrelated party, and whether to split production activities across different locations. The theoretical literature thus helps to explain the circumstances under which outsourcing arises, which can in turn provide useful information on factors behind the increase in the phenomenon in recent 
years and the prospects for future outsourcing. Broadly speaking, the results of the theoretical literature suggest that increased outsourcing comes about from a variety of developments, including lower foreign costs; reduced international transaction costs from globalization and improved technology; and improved institutions and governance in foreign destinations for outsourced activities.

The theoretical literature is generally not yet at the point of showing the impact of outsourcing on workers. An exception is Deardorff (2004), who uses a variant of a Heckscher-Ohlin model to shows that outsourcing can lead wages of unskilled workers in the "North" to actually fall below unskilled wages in the "South," though there are cases in which all workers in the North gain from the possibility of outsourcing.

Meshcheryakova (2005) explores the implications of outsourcing using at a twocountry growth model calibrated roughly to U.S. and Chinese data. Capital is assumed to be a substitute for unskilled labor in producing an intermediate good, which in turn combines with skilled labor to make output. Outsourcing involves producing the intermediate good in the second country (China) and bringing it back to the first country (U.S.) to make the final good. Allowing for outsourcing in this way accounts for the rising skill premium as intermediate production shifts to China, which is abundant in unskilled labor.

Markusen (2005) examines a variety of model structures, including a framework with constant returns and perfect competition, and an alternative with increasing returns and Cournot duopolists. ${ }^{8}$ He looks at models first with skilled and unskilled workers, and then adds the additional factor of knowledge, which is complementary to unskilled workers. He finds that in some cases the advanced economies gain from the possibility of outsourcing, while in others they suffer a welfare loss. When a welfare loss is the result, it comes about through the standard channel of an adverse movement in the terms of trade. Developing countries that are the destination of outsourced activities always gain. Depending on the model, skilled and unskilled workers can either gain or lose from

\footnotetext{
${ }^{8}$ This summary draws heavily on Deardorff (2005).
} 
outsourcing, as can owners of capital. Losses to the various factors come about through increased competition and through the change in the terms of trade. But with a multiplicity of models, Markusen does not pin down a baseline case.

\section{What to do about Offshoring? Implications for Public Policy}

While outsourcing involves real pain to the workers and families who face displacement, the empirical evidence suggests that the hysteria over offshore outsourcing is far out of proportion to its actual impact. Trying to prevent the displacement that results from offshore outsourcing would involve retreating into economic isolationism and giving up the gains from trade. It is better, instead, to focus on providing assistance to people facing dislocation-to focus on things that are real issues and avoid focusing on things that are not problems. This might be too much to ask of our political system.

Increased dislocation from outsourcing suggests a two-fold response. First would be to improve the current set of policies aimed at adjustment assistance. Second would be to create an economic environment with strong growth and robust job creation. Globalization in the 1990's proceeded under the cover of just such job growth.

Finally, it is worth noting, as has been argued by Gary Becker and Richard Posner on their weblog, that outsourcing is to some degree a result of excessively restrictive immigration policy. In a completely free market, the foreign workers would come here to do the work, and the United States would collect more tax revenue for it.

\section{Conclusion}

Offshore outsourcing poses a communications challenge for economists. It can impose serious hardship on workers and their families, and it is no comfort for people facing dislocation that outsourcing provides overall gains for the United States and the world economies. Just as with trade more broadly, communications efforts on 
outsourcing will inevitably involve a substantial defensive component. The positive agenda, meanwhile, is to ensure that the macroeconomic environment provides for broadbased growth and robust job gains. Within this cover, trade can expand into the new channels created by improvements in technology and telecommunications. There is no doubt, however, that discontent arising from outsourcing will be an issue for politicians and economists alike for the foreseeable future.

There is a lot we still do not know about outsourcing, largely because the available data do not provide the information needed to fully understand the magnitude of outsourcing, the reasons behind it, and the effects it has on the economy. What is known, however, suggests several tentative conclusions:

- So far, the extent of outsourcing to date and in the foreseeable future is modest relative to any meaningful labor market indicator.

- As technology develops and global economic integration deepens, more jobs and people will be affected by actual or potential offshore outsourcing. This could affect employment relationships and alter incentives for human capital accumulation. Further development of theoretical models will help foster better understanding of the associated welfare impacts.

- Outsourcing appears to be connected to increased U.S. employment and investment rather than to overall job loss. Some U.S. jobs are certainly lost to other countries. On the whole, however, firms involved with offshore outsourcing are not shifting net jobs overseas but instead are creating jobs both in the United States and in other countries.

Outsourcing will create winners and losers, and the pain of dislocation will be real for workers and their families. Taken together, however, these conclusions suggest that offshore outsourcing is likely to be beneficial for the United States as a whole. This presents a challenge of how to best assist people affected by offshore outsourcing without 
retreating from international engagement and thereby giving up the economic gains that trade in services makes possible. As is the case with more familiar forms of trade, in the long run, outsourcing is likely to be a good thing for the U.S. economy.

\section{References}

Amiti, Mary, and Shang-Jin Wei, 2005. "Fear of Service Outsourcing: Is it Justified?" Economic Policy, April, pp. 308-348.

Amiti, Mary, and Shang-Jin Wei, 2006. "Service Offshoring and Productivity: Evidence from the United States," NBER working paper 11926, January.

Autor David H.; Frank Levy, and R.J. Murnane, 2003. “The Skill Content of Recent Technological Change: An Empirical Exploration," Quarterly Journal of Economics, Volume 118, Number 4, November, pp. 1279-1333(55).

Baily, Martin N., and Diana Farrell, 2004. "Exploding the Myths of Offshoring," McKinsey Quarterly, June.

Baily, Martin N., and Robert Z. Lawrence, 2004. "What Happened to the Great U.S. Job Machine? The Role of Trade and Electronic Offshoring.” Brookings Papers on Economic Activity, September.

Bardhan, Ashok Deo, and Cynthia Kroll, 2003. "The New Wave of Outsourcing," Fisher Center for Real Estate and Urban Economics Research Report, UC Berkeley, Fall.

Bhagwati, Jagdish, Arvind Panagariya and T. N. Srinivasan, 2004. "The Muddles over Outsourcing," Journal of Economic Perspectives, Volume 18, Number 4, Fall, pp. 93114. 
Blinder, Alan S., 2006. “Offshoring: The Next Industrial Revolution?” Foreign Affairs, March/April.

Borga, Maria, 2005. "Trends in Employment at U.S. Multinational Companies: Evidence from Firm-Level Data,” Bureau of Economic Analysis mimeo, September 2005.

Brainard, S. Lael, and David Riker, 1997. “Are U.S. Multinationals Exporting U.S. Jobs?” NBER working paper 5958, March.

Brown, Sharon P., 2004. "Mass Layoff Statistics Data in the United States and Domestic and Overseas Relocation," Bureau of Labor Statistics memo, December. Accessed at http://www.bls.gov/mls/mlsrelocation.pdf

Deardorff, Alan, 2004. "A Trade Theorist's Take on Skilled-Labor Outsourcing," University of Michigan, Ford School of Public Policy, Discussion Paper No. 519, September.

Desai, Mihir A., C. Fritz Foley, and James R. Hines Jr., 2005. "Foreign Direct Investment and Domestic Economic Activity," NBER working paper 11717, October.

Dixit, Avinash, and Gene Grossman, 2005. "The Limits of Free Trade," comment in Journal of Economic Perspectives, Summer, pp. 241-242.

Global Insight, 2005. “The Comprehensive Impact of Offshore Software and IT Services Outsourcing on the U.S. Economy and the IT Industry," Report prepared for Information Technology Association of America, October.

Government Accountability Office (GAO), 2004. "Current Government Data Provide Limited Insight into Offshoring of Services," Report GAO-04-932, September. 
Groshen, Erica L., Bart Hobijn, and Margaret M. McConnell, 2005. "U.S. Jobs Gained and Lost Through Trade: A Net Measure," Federal Reserve Bank of New York Current Issues in Economics and Finance, volume 11 number 8, August.

Hanson, Gordon H., Raymond J. Mataloni, Jr., and Matthew J. Slaughter, 2003.

"Expansion Abroad and the Domestic Operations of U.S. Multinational Firms," mimeo.

Irwin, Douglas, 2005. "Comments on James Markusen," in Brookings Trade Forum on "Offshoring White-Collar Work."

Jensen, J. Bradford, and Lori G. Kletzer, 2005. "Tradable Services: Understanding the Scope and Impact of Services Offshoring," Institute for International Economics working paper 05-9, September.

Kozlow, Ralph H., and Maria Borga, 2004. "Offshoring and the U.S. Balance of Payments," Bureau of Economic Analysis working paper WP2004-05, July.

Krugman, Paul, 1994. "Ricardo's Difficult Idea," Essay available on http://web.mit.edu/krugman/www/ricardo.htm

Landefeld, J. Steven, and Raymond Mataloni, 2004. "Offshore Outsourcing and Multinational Companies,” BEA working paper WP2004-06, July 16, 2004.

Lawrence, Robert Z., 2005. "Offshoring white collar work: exploring the empirics," in Brookings Trade Forum on "Offshoring White-Collar Work."

Mann, Catherine, 2005. "Globalization, Information Technology, and U.S. Economic Performance," January mimeo. 
Markusen, James, 2005. "Modeling the Offshoring of White-Collar Services: From Comparative Advantage to the New Theories of Trade and FDI," in Brookings Trade Forum on "Offshoring White-Collar Work."

Mataloni, Raymond J., Jr., 2005. "U.S. Multinational Companies Operations in 2003," Survey of Current Business, July, pp. 9-29.

McKinsey Global Institute, 2003. “Offshoring: Is it a Win-Win Game?” August.

Meshcheryakova, Yuliya, 2005. "Macroeconomic Effects of International Outsourcing," Victoria University of Wellington, mimeo.

Samuelson, Paul A., 2004. "Where Ricardo and Mill Rebut and Confirm Arguments of Mainstream Economists Supporting Globalization," Journal of Economic Perspectives, Vol. 18 No. 3 Summer 2004, pp. 135-146.

Schultze, Charles L., 2004. "Offshoring, Import Competition, and the Jobless Recovery," Brookings Institution Policy Brief number 136.

Spencer, Barbara, 2005, "International Outsourcing and Incomplete Contracts," NBER working paper 11418, June.

Trefler, Daniel, 2005. "Offshoring: Threats and Opportunities," in Brookings Trade Forum on "Offshoring White-Collar Work." 